\title{
Comparative analysis of foraging and habitat use by the sympatric Caribbean parrotfish Scarus vetula and Sparisoma viride (Scaridae)
}

\author{
J. Henrich Bruggemann ${ }^{1}$, Maarten W. M. Kuyper ${ }^{2}$, Anneke M. Breeman ${ }^{1}$ \\ ${ }^{1}$ Department of Marine Biology, University of Groningen, PO Box 14, 9750 AA Haren, The Netherlands \\ ${ }^{2}$ Delft Hydraulics, Water Resources and Environment Division, PO Box 177, $2600 \mathrm{MH}$ Delft, The Netherlands
}

\begin{abstract}
On the fringing reef of Bonaire, Netherlands Antilles, a comparative study was made of habitat use, diet selection, foraging behaviour and food acquisition of the parrotfish species Scarus vetula and Sparisoma viride. The species are sympatric and live in the same reef habitats (depth zones). Both species show similar foraging selectivity, but exploit algal resources differently. Preferred food items are turf algae on substrates infested with endolithic algae, whereas crustose corallines are avoided. Foraging preferences are related to yield, i.e. the amount of AFDW (ash-free dry weight), protein and energy that can be harvested per bite. Foraging behaviour differs between the species. $S$. vetula takes more bites in long forays, has higher bite rates (no. of bites $\mathrm{s}^{-1}$ ), and makes fewer and smaller scars on grazing substrates than $S$. viride. Furthermore, $S$. vetula prefers flat substrate surfaces while adult $S$. viride graze by preference on concave surfaces. Species-specific differences in preference and utilization of grazing substrates are related to feeding mode. $S$. vetula employs a scraping feeding mode by which mainly epilithic algae are ingested. In contrast, $S$. viride is an excavating grazer that ingests large amounts of endolithic and crustose algae. Intake and assimilation of algal AFDW, protein and energy were quantified through a combination of laboratory feeding trials and field observations. $S$, vetula has lower food intake $\left(\mathrm{mg} \mathrm{AFDW}\right.$ bite $\left.{ }^{-1}\right)$ than $S$, viride $\left(0.8 \times 10^{-3} \times\right.$ fish wet wt, FWW, and $2.3 \times 10^{-3} \times$ FWW respectively), resulting from smaller (shallower) bites. Assimilation efficiencies of total AFDW, protein and energy by $S$. vetula were higher than in $S$. viride grazing on the same dead coral substrates. In spite of different feeding modes and different fractions of the primary production harvested, daily amounts of assimilated nutrients and energy are similar for both species, resulting from higher feeding rates (no. of bites $\mathrm{h}^{-1}$ ) and higher assimilation efficiency in S. vetula.
\end{abstract}

KEY WORDS: Coral reefs · Herbivory - Scaridae - Diet selection - Daily food consumption · Foraging behaviour - Competition

\section{INTRODUCTION}

On coral reefs, numerous herbivorous species coexist. The majority of these species depend on benthic algae as the primary source of food (Russ \& St. John 1988). Natural or manipulative experiments in the Caribbean have indicated that herbivores compete for food and space. For instance, the removal of Diadema antillarum resulted in higher densities of herbivorous fish (Hay \& Taylor 1985, Carpenter 1990, Robertson 1991). However, in other studies no such increase in herbivore populations was found after large expansions in their food supply (Wellington \& Victor 1985,
Williams 1986). Interspecific competition is likely to occur when the resources used are overlapping (Ogden \& Lobel 1978, Steneck 1983), and may lead to resource partitioning between species (Schoener 1974, Ebersole 1985).

In models of plant-herbivore interactions (Steneck 1988) and in studies on the trophodynamics of coral reefs (Hatcher 1983, Hatcher \& Larkum 1983, Carpenter 1986), herbivorous fish have often been divided into broad functional categories. Scarids were regarded as a relatively uniform group of herbivores grazing on algal turfs (Goldman \& Talbot 1976, Russ $1984 \mathrm{a}, \mathrm{b})$. This assumption was recently questioned, 
and rejected, by Bellwood \& Choat (1990). On the basis of foraging behaviour and the morphology and myology of jaw structures of scarids from the Great Barrier Reef, they concluded that parrotfish can be divided into scrapers (including sand suckers) and excavators. These differences in feeding mode will determine the impact of their grazing on the algal food sources, as well as on bioerosional processes on the reef (Frydl \& Stearn 1978).

In the tropical Western Atlantic 14 scarid species are found (Randall 1968, Choat 1991), of which 10 are common to coral reef habitats. Some spatial separation occurs over different reef areas (e.g. exposed vs sheltered coasts), habitat types (e.g. sand vs coral rubble substrates), or depth zones. Some scarids appear to have specialized feeding habits, e.g. sand sucking by Scarus coerulus, but most species apparently forage on benthic algae that are associated with hard substrates. On the fringing reef of Bonaire, Netherlands Antilles, 2 scarid species are the most abundant, in terms of both number of individuals and biomass (J. H. Bruggemann unpubl. results): Scarus vetula and Sparisoma viride. Both species occupy the same reef habitats, and appear to utilize the same algal resources. Yet they graze alongside each other, seemingly without much interspecific aggressive interaction.

A comparative study of foraging and habitat use by these common reef herbivores was performed as part of a larger project, aiming to evaluate the role of parrotfish in the trophodynamics of coral reefs. Foraging behaviour and habitat use of both species are characterized here. Foraging selectivity and daily food acquisition by Scarus vetula are described and compared to data obtained for Sparisoma viride from the same study area, as described by Bruggemann et al. (1994a, b). A quantitative estimate of the impact of these species on the algal food sources, and their role in coral reef trophodynamics, is given elsewhere (J. H. Bruggemann, J. M. van Rooij, J. J. Videler \& A. M. Breeman unpubl.).

Our specific questions are: (1) What are the differences in foraging behaviour between the species? (2) Do both species select and utilize the same resources? (3) How do they compare in food intake and assimilation?

\section{MATERIALS AND METHODS}

Study area and quantification of algal resources and grazing substrates. The study was performed on the fringing reef in front of the Karpata Ecological Centre, situated on the leeward coast of Bonaire $\left(12^{\circ} 13^{\prime} \mathrm{N}\right.$, $\left.68^{\circ} 20^{\prime} \mathrm{W}\right)$. The reef profile typically comprises:

- a $30 \mathrm{~m}$ wide shallow reef zone ( 0 to $3.5 \mathrm{~m}$ depth). dominated by coarse rubble from dead Acropora palmata colonies, interspaced with patches of live coral of the same species;

- a $26 \mathrm{~m}$ wide gorgone zone ( 3.5 to $6 \mathrm{~m}$ depth), of which the bottom is formed by a fossil carbonate platform, covered in large part with sediment and rubble of $A$. cervicornis;

- a $17 \mathrm{~m}$ wide drop-off zone (6 to $12 \mathrm{~m}$ depth), dominated by massive heads of Montastrea annularis;

- a $15 \mathrm{~m}$ wide upper reef slope (12 to $25 \mathrm{~m}$ depth), where coral cover is dominated by colonies of $M$. annularis and Agaricia agaricites. A detailed description of the reef at the study area is provided by Bruggemann et al. (1994a).

All field observations were made using SCUBA, while notes were recorded on PVC sheets. The abundance of different food and substrate types in each reef zone was quantified using chain-link transects (Porter 1972) as described by Bruggemann et al. (1994a). Non-algal biota were identified to the species level and subsequently grouped in 2 categories: living corals and other biota. Algal vegetation was divided into categories according to the height of the epilithic algal fronds and the type of undergrowth of the algal community (endolithic algae or crustose corallines). The categories were: large turfs including macroalgae (fronds $>3.5 \mathrm{~mm}$ in height), sparse turfs (fronds 0.1 to $3.5 \mathrm{~mm}$ ) growing on substrates containing endolithic algae, sparse turfs growing on crustose corallines, bare coralline crusts, and sedimented algal turfs (of all frond heights). The undergrowth of large turfs consisted mainly of endolithic algae. Biochemical composition of algal vegetation was determined by Bruggemann et al. (1994a: Table 5). Whenever possible, the coral origin of substrates was identified to the species level from the shape and the structure of the rock. Skeletal density of substrates was determined by Bruggemann et al. (1994a).

Study animals. Scarus vetula is a large herbivorous reef fish, attaining a maximum size of ca $50 \mathrm{~cm}$ fork length, FL, measured from the tip of the upper jaw to the end of the middle caudal rays. The species is protogynous, and shows full sexual dichromatism (Randall 1968, Robertson \& Warner 1978). In the field 3 life phases are distinguished, according to coloration and reproductive behaviour: juveniles (JU: $<15 \mathrm{~cm}$ FL), initial phase (IP: 15 to $35 \mathrm{~cm}$ FL) and terminal phase males (TP: 28 to $50 \mathrm{~cm} \mathrm{FL).} \mathrm{JU} \mathrm{and} \mathrm{IP} \mathrm{fish} \mathrm{are} \mathrm{coloured}$ greyish to reddish brown with a broad white stripe on the lower side. TP males are gaudily coloured blue and blue-green, with rose and orange stripes on head and pelvic fins. The species is common to occasional in the tropical western Atlantic (Robertson \& Warner 1978).

Sparisoma viride is also a large herbivorous fish, attaining a maximum size of $45 \mathrm{~cm} \mathrm{FL}$, and is common to Caribbean reefs. J. M. van Rooij, F. Kroon \& J. J. 
Videler (unpubl.) provide a detailed description of the social structure and mating system of $S$. viride.

Parrotfish population density was monitored from February 1989 to January 1991 as described elsewhere (Bruggemann et al. unpubl.). At the study site Scarus vetula is the most abundant species, both in number of individuals and in biomass. The second most abundant parrotfish species is Sparisoma viride. The spatial distributions of both species coincide, with highest biomass and highest densities of adult fish found in the shallow reef zone.

Field description of individual bites and forays. Diet composition of Sparisoma viride was described by Bruggemann et al. (1994a). Diet composition of Scarus vetula was monitored in the same way. The percentage cover of algal food types was estimated to the nearest $10 \%$ at the precise location of a bite. Also noted were: fork length of fish (estimated to the nearest $\mathrm{cm}$ ), life phase, depth, substrate 'microhabitat', coral origin of the substrate, and the presence or absence of a grazing scar. Two microhabitat types were distinguished: flat (including concave) and convex surfaces. Per reef zone, the frequency distributions of algal food and dead coral substrate types in the diets of different life phases were tested with chi-square (Norusis 1990) against the frequency distribution of food and substrate types present on the reef.

Additional data on diet composition were collected by description of feeding forays. A foray is defined as a feeding event of successive bites without discernible interval, other than that necessary to reapply the jaws to the substratum (Bellwood \& Choat 1990). In addition to all variables recorded for individual bites, foray size (no. of bites per foray) and foray length (seconds) were also determined. The effects of food type, substrate microhabitat, substrate skeletal density and foraging depth on the frequency distribution of total bites by foray size were tested with chi-square. Bite rate (no. of bites $\mathrm{s}^{-1}$ ) was estimated from the leastsquares regression of foray size to foray length. Differences in bite rate between Scarus vetula and Sparisoma viride were tested by comparison of regression slopes using an approximate $t$-test as described Sokal \& Rohlf (1981).

Size of grazing scars and estimated yield per bite. The surface area $(S A)$ removed and the volume $(V O)$ of substrate excavated per bite by Scarus vetula were quantified in the same way as previously described for Sparisoma viride (Bruggemann et al. 1994a). Analysis of covariance (ANCOVA; Norusis 1990) with food type, substrate density and substrate microhabitat as main effects, and $\mathrm{FL}^{2}$ or $\mathrm{FL}^{3}$ as covariate of $S A$ and $V O$ respectively, was used to investigate factors affecting bite size. Data were transformed (square root of $S A$, cube root of $\mathrm{VO}$ ) to meet conditions of normality and homogeneity of variances, while homogeneity of slopes was tested in each analysis of covariance. Size of bite scars made by $S$. vetula and $S$. viride was compared by testing for homogeneity of slopes of the linear regressions of bite scar surface area to $\mathrm{FL}^{2}$ and scar volume to $\mathrm{FL}^{3}$ (approximate $t$-test; Sokal \& Rohlf 1981).

The potential yield of food (mg ash-free dry wt, AFDW), protein (mg) and energy ( $\mathrm{kJ}$ ) per bite from different food types was calculated from the surface area of grazing scars and from the biochemical composition of the food. Estimates of the yield per bite were made for fish of $30 \mathrm{~cm} \mathrm{FL}$, and it was assumed that all algal material that was scraped off the dead coral substrates was ingested by the fish. By relating the total food intake per bite as determined experimentally (see below \& Bruggemann et al. 1994b) to the surface area of grazing scars and to the biomass of epilithic and 'substrate-bound' algal fractions (i.e. endolithic algae and crustose corallines), it was inferred that on average $2 \%$ of the biomass of substrate-bound algae present under the surface area of a grazing scar is harvested by a fish of $30 \mathrm{~cm}$ FL.

Food intake experiments. Food intake experiments with Scarus vetula were carried out in tanks as described by Bruggemann et al. (1994b). The amount of algal food ingested per bite was calculated from the decrease in algal biomass ( $\mathrm{mg}$ AFDW $\mathrm{cm}^{-2}$ ) after a known number of bites on blocks of dead coral substrate covered with a natural vegetation. Blocks of dead coral bearing a homogeneous algal vegetation, and representing characteristic food and substrate types, were collected from the shallow reef zone, the main feeding area of $S$. vetula. Each experiment consisted of a series of experimental blocks offered to a fish (or pair of fish) of known weight. Fish wet wt (FWW) was determined as described by Bruggemann et al. (1994b). The coral origin of the substrate, as well as algal biomass, height and percentage cover of filamentous algal fronds, percentage cover of crustose corallines, and thickness of the endolithic layer on experimental and control blocks were noted. We first tested whether food intake per bite differed between substrate types (ANCOVA in which fish weight was taken as covariate) (Norusis 1990). If not, substrate types were pooled, and the effect of algal vegetation parameters on food intake per bite was analyzed, using analysis of variance (ANOVA) and multiple regression. Multiple regression analysis showed that food intake per bite increases with fish weight and algal biomass. The mean algal biomass of substrates differed significantly between experiments (Scheffé's test, $\left.F_{\{3,40\}}=9.53, \mathrm{p}<0.001\right)$, affecting food intake per bite. This experimental bias was eliminated by correcting food intake per bite for differences in algal biomass between experiments using the corresponding regression equations. 
Epilithic and substrate-bound algal fractions differ in biochemical composition (Bruggemann et al. 1994a). In order to enable estimation of protein and energy intake per bite, the relative proportion of epilithic and substrate-bound algae in the diet was assessed. The percentage of the total food intake per bite that was derived from substrate-bound fractions was calculated from the total food intake per bite minus the intake derived from epilithic algae. Ingestion of epilithic algae was calculated from the surface area of grazing scars and the epilithic biomass. Biomass of epilithic algae on Acropora substrates was determined by Bruggemann et al. (1994a, Table 5: sparse turfs on endolithic algae $=1.3 \pm 0.1 \mathrm{mg} \mathrm{AFDW} \mathrm{cm}^{-2}$; sparse

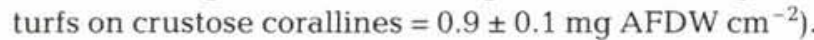
From the relative abundance of endolithic algae and crustose corallines on experimental substrates, it was estimated that the biomass of epilithic algae averaged

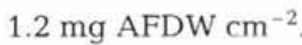

To verify the validity of the experimentally determined food intake per bite of Scarus vetula, the size of grazing scars from captive fish were compared to those from fish foraging on the reef. In the laboratory, the surface area and volume of scars on Acropora cervicornis and A. palmata substrates were determined for 100 visible scars caused by fish of $30 \mathrm{~cm} \mathrm{FL}(\mathrm{n}=50)$ and $36 \mathrm{~cm}$ FL $(\mathrm{n}=50)$ that were kept in tanks. Differences in mean surface area or volume of grazing scars between captive and free-living fish were small and not significant (in all $t$-tests: $p>0.05$ ). For $S$. vetula of $30 \mathrm{~cm}$ FL there was no difference in the size of grazing scars made in captivity or in the field. For larger fish ( $>30 \mathrm{~cm}$ FL), the mean correction factor (field bites/ captive bites) for the surface area is 1.18, and for volume 1.49, indicating that large free-living fish on average take larger bites than similarly sized fish in captivity.

Food assimilation experiments. Assimilation efficiency of algal food by Scarus vetula was determined by quantitative measurement of food consumed and faeces produced. The advantages of this direct method as compared to indirect methods employing ash-markers is discussed by Bruggemann et al. (1994b). Fish were fed ad libitum on a diet of coral rubble with associated algae that were collected from the same locality (the shallow reef zone), originating from the same coral species and supporting similar algal biomass, as was used in the food intake experiments. Assimilation trials were performed following the procedures described by Bruggemann et al. (1994b). Daily intake of algal food ( $m g$ AFDW $_{\text {in }}$ ) was calculated as the product of the daily total number of bites and the experimentally determined food intake per bite for each fish or pair of fish. Biochemical composition of faeces was corrected for the loss of organic matter and nutrients between egestion and analysis of faeces, and was assumed to be the same as found for Sparisoma viride (Bruggemann et al. 1994b). Daily excretion of organic matter (mg $\mathrm{AFDW}_{\text {ex }}$ ) was calculated as the product of faeces dry weight and the corrected organic fraction. The 'total assimilation efficiency' (\%), i.e. the proportion of the total algal AFDW that was absorbed, was calculated as:

$$
\left[\left(\mathrm{AFDW}_{\text {in }}-\mathrm{AFDW}_{\mathrm{ex}}\right) / \mathrm{AFDW}_{\text {in }}\right] \times 100 .
$$

Assimilation efficiencies for protein and energy were also determined by quantifying total daily intake and egestion of these nutrients. Daily intakes of protein and energy were calculated from ingested AFDW (see Fig. 6A), the relative amounts of epilithic and substrate-bound algae in the diet of experimental fish (Fig. 6C), and their biochemical composition (Table 5 in Bruggemann et al. 1994a). Daily excretions of protein and energy were determined from the egested AFDW and the protein and energy contents of the faeces. Protein and energy content of food and faeces was determined as described by Bruggemann et al. (1994a). The 'nutrient assimilation efficiency' (\%), which is the proportion of a given nutrient that was assimilated, was calculated as:

$$
\frac{\% \text { nutrient } \times \mathrm{AFDW}_{\text {in }}-\% \text { nutrient } \times \mathrm{AFDW}_{\mathrm{ex}}}{\% \text { nutrient } \times \mathrm{AFDW}_{\text {in }}} \times 100 \text {. }
$$

Daily foraging effort. For Scarus vetula, the feeding rate $\left(\mathrm{FR}\right.$, no. of bites $\mathrm{h}^{-1}$ ) was determined during $30 \mathrm{~min}$ observation periods. Individual fish foraging on the shallow reef were followed after a brief acclimation period, during which fork length was estimated to the nearest $\mathrm{cm}$, and life phase, time of day and temperature (recorded at $6 \mathrm{~m}$ depth) were noted. The effects of fork length, life phase, temperature and season on FR were investigated in observation series, carried out intermittently from January to August 1990, aiming to encompass the widest range in seasonal temperature fluctuations. During each observation series, FR of fish from 4 distinct size classes, i.e. JU fish of $10 \pm 1 \mathrm{~cm} \mathrm{FL}$, IP fish of $20 \pm 1 \mathrm{~cm} \mathrm{FL}$, IP fish of $29 \pm 2 \mathrm{~cm} \mathrm{FL}$, and TP fish of $40 \pm 2 \mathrm{~cm}$, was determined. For each size class, the FRs of 3 different individuals were recorded. The feeding activity varies over the day, but was relatively constant between 12:00 and 17:00 h. Therefore, factors affecting FR were investigated based on observations made between 12:00 and 17:00 h, using ANOVA.

The total daily number of bites was determined for IP fish of $29 \pm 2 \mathrm{~cm}$ FL from series of observations in which the feeding activity at regular intervals from dawn to dusk was monitored ('daycovers'). Length of daylight period is defined as the time in hours from sunrise to sunset, and was calculated for the latitude of 
the study area using equations described by Dring (1984). Three complete daycovers were made in January, April and August 1990. Using these daycover observations, the relationship between daily foraging period, FR between 12:00 and 17:00 h and total daily bites was determined empirically.

\section{RESULTS}

\section{Foraging behaviour}

The frequency distribution of total bites by foray size differed significantly between adult Scarus vetula and Sparisoma viride (Fig. 1). S. vetula takes a significantly larger proportion of bites during long forays ( $>10$ bites) than $S$. viride $\left(\chi_{1}^{2}=196.30, \mathrm{p}<0.001\right)$.

Bite rate of Scarus vetula was higher than that of Sparisoma viride, as demonstrated by the inequality of slopes (approximate $t$-test, $t_{0.001(301)}=35.53, \mathrm{p}<0.001$ ) of the linear regression of foray size to foray length (Fig. 2). When analyzed separately for juvenile and adult fish, bite rate of $S$. vetula was always higher than that of $S$. viride (approximate $t$-test, juveniles: $t_{0.001(46)}=$ $35.53, \mathrm{p}<0.001$; adults: $t_{0.001(254)}=34.33, \mathrm{p}<0.001$ ).

Most bites taken by both juvenile and adult Scarus vetula did not leave grazing scars that could be detected under water (Fig. 3), but adults left scars more often than juveniles. Similarly, the majority of the bites taken by juvenile Sparisoma viride left no grazing scars (Fig. 3). In contrast, almost $80 \%$ of the bites taken by adult $S$. viride did leave scars on the substrate.

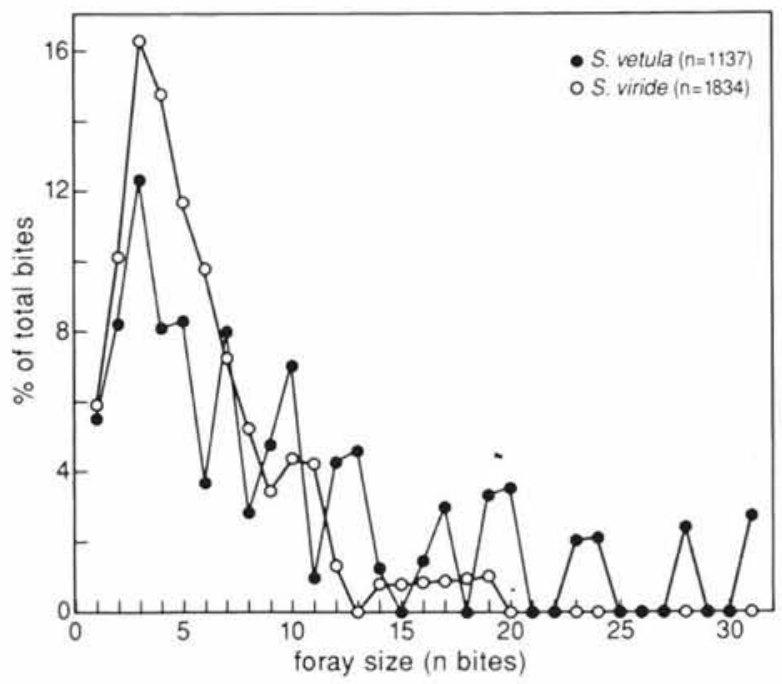

Fig. 1. Scarus vetula and Sparisoma viride. Frequency distribution of total bites by foray size for adult parrotfish. $n$ : total number of bites observed

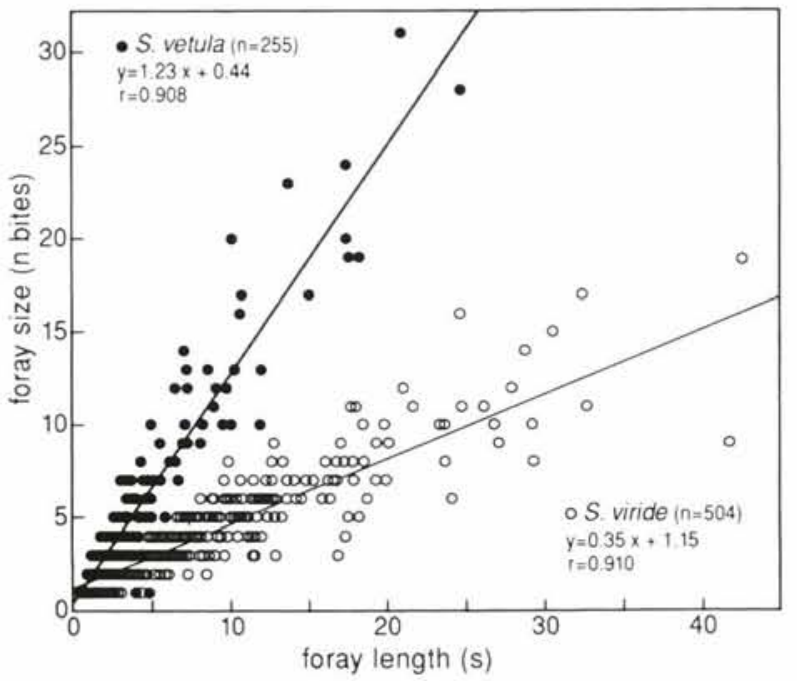

Fig. 2. Scarus vetula and Sparisoma viride. Bite rate (no. of bites $\mathrm{s}^{-1}$ ) of parrotfish expressed as a regression of foray size on foray length. For clarity, only data for adult fish are shown; $\mathrm{n}$ above equations indicates total number of forays observed

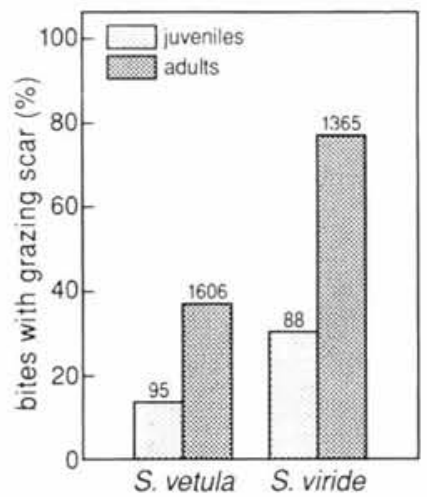

Fig. 3. Scarus vetula and Sparisoma viride. Relative occurrence of grazing scars by juvenile and adult parrotfish. Num-

bers above bars indicate the number of bites observed

\section{Size of grazing scars}

The surface area of grazing scars left by Scarus vetula is linearly related to $\mathrm{FL}^{2}$, as determined by linear regression of log-transformed data. Bite scar volume is linearly related to $\mathrm{FL}^{3}$. The intercepts of the least-squares regressions of bite scar surface area ( $S A$, $\left.\mathrm{cm}^{2}\right)$ and of bite scar volume $\left(\mathrm{VO}, \mathrm{cm}^{3}\right)$ to fish FL $(\mathrm{cm})$ were not significantly different from zero. Therefore the linear regressions were forced through the origin. The regression equations are:

and

$$
\begin{gathered}
S A=4.013(\mathrm{SD}: \pm 0.241) \times 10^{-4} \times \mathrm{FL}^{2}, \\
\mathrm{r}=0.821, \mathrm{n}=135, \mathrm{p}<0.001 \\
V O=0.194(\mathrm{SD}: \pm 0.020) \times 10^{-6} \times \mathrm{FL}^{3}, \\
\quad \mathrm{r}=0.647, \mathrm{n}=132, \mathrm{p}<0.001 .
\end{gathered}
$$


One-way ANCOVA, in which $\mathrm{FL}^{2}$ and $\mathrm{FL}^{3}$ were taken as covariates of $S A$ and $V O$ respectively, failed to detect significant effects of food type, substrate density, or substrate microhabitat on the size of grazing scars made by Scarus vetula.

Comparison of the slope of the regression equations showed that the surface area of grazing scars made by Scarus vetula is ca $30 \%$ smaller, while the volume of scars is ca $86 \%$ smaller, than those made by Sparisoma viride (for regression equations for $S$. viride see Bruggemann et al. 1994b: p. 47). These differences in size of grazing scars between species are significant (approximate $t$-test; scar surface area: $t_{0.001(135)}=6.14$. $\mathrm{p}<0.001$; scar volume: $\left.t_{0.001(135)}=17.41, \mathrm{p}<0.001\right)$.

\section{Selection and utilization of grazing substrates}

The relative abundance of different substrate types was compared to the relative frequency of bites taken on these substrates by Scarus vetula and Sparisoma viride (Table 1). In all reef zones, both parrotfish species avoided grazing on living coral and other non-algal biota. However, $S$. viride took bites from these biota more often than did $S$. vetula. Dead coral and coral rubble were grazed upon preferentially by both species. Coral bases, the rising and tilting sides of coral colonies not covered with living coral polyps, were avoided by both species in all reef zones, except for $S$, viride in the gorgone zone, where this substrate type was grazed upon approximately in proportion to its relative abundance. The carbonate platform, an essentially flat surface that is found only in the gorgone zone, was preferred by $S$, vetula, but avoided by $S$. viride. Sandy bottoms were avoided by both species.

Preference for different dead coral substrates was tested for each life phase of Scarus vetula, by comparing the relative abundance of substrates to the relative frequency of bites taken on these substrate types (Table 2). Only dead coral substrates that were covered with benthic algae are included in the comparisons. On the shallow reef, JU and IP fish preferred dead Montastrea annularis substrates to Acropora cervicornis substrates, whereas TP fish showed no significant preference for any substrate type in this reef zone. In the gorgone zone, TP males showed a preference for $M$. annularis substrates, avoiding $A$. cervicornis substrates, whereas JU and IP fish showed no significant preference for any dead coral substrate in this reef zone. In the drop-off zone, neither IP nor TP fish showed a significant preference for any substrate type. In the shallow reef zone, preferential grazing on $M$. annularis substrates can be explained by differences in algal vegetation, as these substrates are covered to a larger extent with sparse turfs on an undergrowth of endolithic algae (a preferred food type; see below) than are dead $A$. cervicornis substrates (35 and 9\% respectively). However, in the gorgone zone, the cover of sparse turfs on endolithic algae did not differ between dead $M$. annularis and $A$. cervicornis substrates ( 24 and $25 \%$ respectively), and offers no expla-

Table 1. Relative frequencies (\%) of bites taken by Scarus vetula and Sparisoma viride on different substrate types, compared to their relative abundance $(\%)$ on the reef

\begin{tabular}{|c|c|c|c|c|c|c|}
\hline $\begin{array}{r}\text { Reef zone } \\
\text { Species }\end{array}$ & $\begin{array}{c}\text { Living coral } \\
+ \text { other } \\
\text { non-algal biota }\end{array}$ & $\begin{array}{l}\text { Dead coral + } \\
\text { coral rubble }\end{array}$ & $\begin{array}{l}\text { Coral } \\
\text { bases }\end{array}$ & $\begin{array}{l}\text { Carbonate } \\
\text { platform }\end{array}$ & $\begin{array}{l}\text { Sandy } \\
\text { bottom }\end{array}$ & $\begin{array}{l}\text { No. of } \\
\text { chain-links } \\
\text { or bites }\end{array}$ \\
\hline $\begin{array}{l}\text { Shallow reef } \\
\text { Available: }\end{array}$ & 10.8 & 82.8 & 6.2 & 0.0 & 0.2 & 4437 \\
\hline $\begin{array}{l}\text { Eaten by: } \\
\text { S. vetula } \\
\text { S. viride }\end{array}$ & $\begin{array}{l}0.2 \\
1.0\end{array}$ & $\begin{array}{l}99.8 \\
97.0\end{array}$ & $\begin{array}{l}0.0 \\
2.0\end{array}$ & - & $\begin{array}{l}0.0 \\
0.0\end{array}$ & $\begin{array}{l}424 \\
204\end{array}$ \\
\hline $\begin{array}{l}\text { Gorgone zone } \\
\text { Available: }\end{array}$ & 25.5 & 36.8 & 6.0 & 12.7 & 19.0 & 6363 \\
\hline $\begin{array}{l}\text { Eaten by: } \\
\text { S. vetula } \\
\text { S. viride }\end{array}$ & $\begin{array}{l}0.0 \\
2.8\end{array}$ & $\begin{array}{l}67.0 \\
83.2\end{array}$ & $\begin{array}{l}2.9 \\
7.7\end{array}$ & $\begin{array}{r}29.5 \\
4.5\end{array}$ & $\begin{array}{l}0.6 \\
1.8\end{array}$ & $\begin{array}{l}339 \\
285\end{array}$ \\
\hline $\begin{array}{l}\text { Drop-off } \\
\text { Available: }\end{array}$ & 43.7 & 21.8 & 25.9 & 0.0 & 8.6 & 4952 \\
\hline $\begin{array}{l}\text { Eaten by: } \\
\text { S. vetula } \\
\text { S. viride }\end{array}$ & $\begin{array}{l}0.0 \\
5.1\end{array}$ & $\begin{array}{l}85.7 \\
79.1\end{array}$ & $\begin{array}{r}9.2 \\
14.7\end{array}$ & - & $\begin{array}{l}5.1 \\
1.1\end{array}$ & $\begin{array}{l}196 \\
353\end{array}$ \\
\hline
\end{tabular}




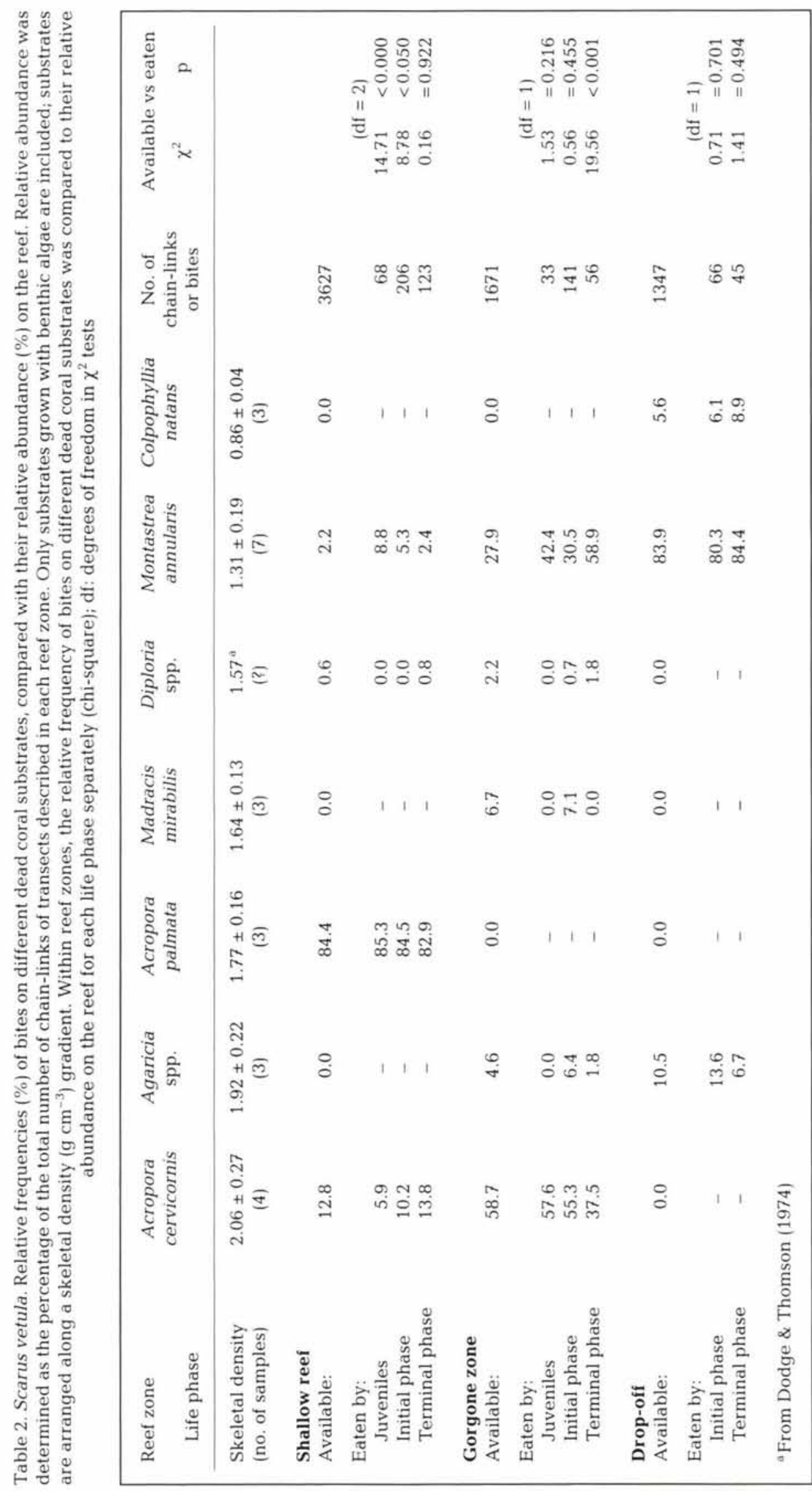




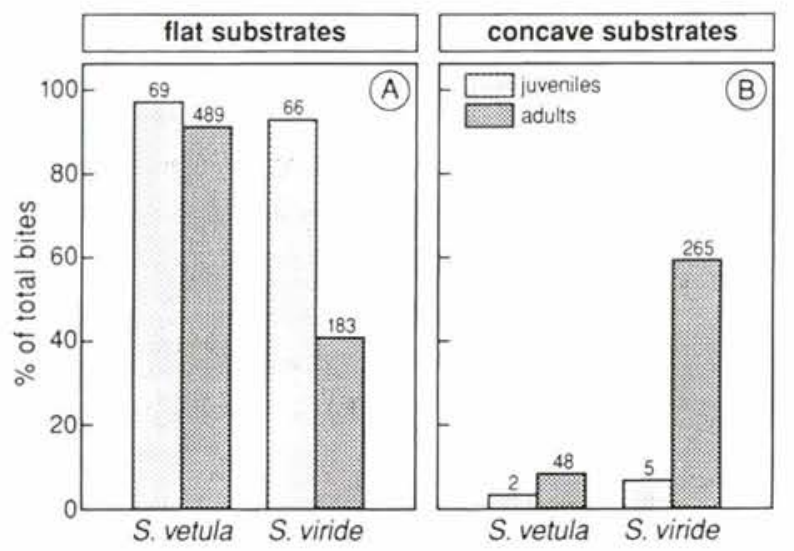

Fig. 4. Scarus vetula and Sparisoma viride. Relative occurrence of bites taken by juvenile and adult parrotfish on substrates with (A) flat and (B) concave microhabitat. Numbers above bars indicate the number of bites observed

nation for preferential feeding on dead $M$. annularis substrates by TP males.

Preference for substrate microhabitat is shown in Fig. 4. In Scarus vetula both juvenile and adult fish prefer to graze on flat substrate surfaces (Fig. 4A). Juvenile Sparisoma viride also graze by preference on flat surfaces (Fig. 4B), but adult $S$. viride take more bites on convex than on flat surfaces.

\section{Selection of food types}

Scarus vetula feeds virtually exclusively on turf algae. Bites on macroalgae, such as Dictyota spp. or Lobophora variegata, were never observed. Of all bites (and forays) described ( $\mathrm{n}=965)$, only 3 were taken on biota other than algae: 1 bite was seen taken on the hydrocoral Millepora complanata, while bites taken from unidentified encrusting sponges were recorded twice. Bites taken on bare sand were not observed. Bites on sedimented algal turfs constituted a minor proportion $(3.5 \%)$ of the diet of $S$. vetula. In the subsequent analysis of foraging selectivity, only vegetation categories that constituted a major proportion of the diet $(>5 \%)$ were included: large turfs, sparse turfs on endolithic algae, sparse turfs on crustose corallines, and bare coralline crusts.

In Table 3 the diet composition of the different life phases and the relative abundance of the major food types are given for each reef zone. Diet composition differed between life phases on the shallow reef $\left(\chi^{2}{ }_{4}=\right.$ 28.27, $\mathrm{p}<0.001)$ and on the gorgone zone $\left(\chi_{6}^{2}=13.09\right.$, $\mathrm{p}<0.050$ ), whereas on the drop-off zone diet composition of IP fish did not differ significantly from that of TP males $\left(\chi^{2}{ }_{3}=4.23, \mathrm{p}=0.237\right)$. No JU Scarus vetula were observed grazing on the drop-off zone.

For all life phases in all reef zones the frequency distribution of food types in the diet differed signifi-

Table 3. Scarus vetula. Relative abundance (\%) of the main algal food types, and relative frequencies (\%) of bites on these food types. Relative abundance was determined as the percentage of the total number of chain-links on transects described in each reef zone. Within reef zones, the relative frequency of bites on algal food types was compared to their relative abundance on the reef for each life phase separately (chi-square)

\begin{tabular}{|c|c|c|c|c|c|c|c|}
\hline \multirow{2}{*}{$\begin{array}{l}\text { Reef zone } \\
\text { Life phase }\end{array}$} & \multirow{2}{*}{$\begin{array}{c}\text { Large turfs } \\
+ \text { macroalgae }\end{array}$} & \multirow{2}{*}{$\begin{array}{l}\text { Sparse turfs } \\
\text { on endolithic } \\
\text { algae }\end{array}$} & \multirow{2}{*}{$\begin{array}{l}\text { Sparse turfs } \\
\text { on crustose } \\
\text { corallines }\end{array}$} & \multirow{2}{*}{$\begin{array}{l}\text { Crustose } \\
\text { coallines }\end{array}$} & \multirow{2}{*}{$\begin{array}{l}\text { No. of } \\
\text { chain-links } \\
\text { or bites }\end{array}$} & \multicolumn{2}{|c|}{ Available vs eaten } \\
\hline & & & & & & $\chi_{3}^{2}$ & $\mathrm{p}$ \\
\hline \multicolumn{8}{|l|}{ Shallow reef } \\
\hline Available: & 3.5 & 22.9 & 54.6 & 19.0 & 3802 & & \\
\hline \multicolumn{8}{|l|}{ Eaten by: } \\
\hline Juveniles & 0.0 & 38.9 & 43.1 & 18.0 & 72 & 12.19 & $<0.010$ \\
\hline Initial phase & 1.9 & 46.3 & 33.5 & 18.3 & 218 & 66.23 & $<0.000$ \\
\hline Terminal phase & 3.9 & 69.5 & 15.6 & 10.9 & 128 & 150.58 & $<0.000$ \\
\hline \multicolumn{8}{|l|}{ Gorgone zone } \\
\hline Available: & 13.9 & 17.4 & 57.5 & 11.2 & 2723 & & \\
\hline \multicolumn{8}{|l|}{ Eaten by: } \\
\hline Juveniles & 2.4 & 35.7 & 47.6 & 14.3 & 42 & 12.82 & $<0.010$ \\
\hline Initial phase & 8.6 & 41.6 & 28.2 & 21.5 & 209 & 110.54 & $<0.000$ \\
\hline Terminal phase & 10.5 & 46.3 & 33.7 & 9.5 & 95 & 51.72 & $<0.000$ \\
\hline \multicolumn{8}{|l|}{ Drop-off } \\
\hline Available: & 20.5 & 8.1 & 54.8 & 16.6 & 2369 & & \\
\hline \multicolumn{8}{|l|}{ Eaten by: } \\
\hline Initial phase & 15.9 & 52.3 & 17.0 & 14.8 & 88 & 194.57 & $<0.000$ \\
\hline Terminal phase & 22.5 & 59.2 & 11.3 & 7.0 & 71 & 215.74 & $<0.000$ \\
\hline
\end{tabular}


cantly from the frequency distribution of available food types. Sparse turfs growing on substrates containing endolithic algae were preferred by all Scarus vetula (Table 3). In all reef zones, JU and IP S. vetula fed less on large turfs than would be expected if fish fed randomly on the main food types. TP fish, however, fed in proportion to the relative abundance of large turfs in each reef zone. Sparse turfs growing on crustose corallines were avoided by all life phases on all reef zones. Bare coralline crusts were grazed upon approximately in proportion to their relative abundance on the reef by JU and IP fish, but they were avoided by TP males.

\section{Foray size in relation to food type and substrate microhabitat}

Foray size in Scarus vetula was not correlated with fish size $(\mathrm{r}=0.051, \mathrm{n}=302, \mathrm{p}=0.381)$, and the frequency distribution of foray sizes did not differ statistically between life phases (Kolmogorov-Smirnov tests; all pairs: $p>0.05$ ). Therefore, data on foray size of all life phases were pooled. Foray size was divided into 4 classes: $1-5,6-10,11-15$, and $>15$ successive bites within a foray. The frequency distribution of total bites by foray size differed between vegetation types (Fig. $5 \mathrm{~A}_{;} \chi^{2}{ }_{6}=32.68, \mathrm{p}<0.001$ ). Fish grazing on turfs that grow on substrates containing endolithic algae took more bites in succession, resulting in a larger proportion of the total bites taken in long forays, compared to fish grazing on either turfs on crustose corallines or bare coralline crusts $\left(\chi^{2}{ }_{3}=10.22, p<\right.$ 0.05). Furthermore, in longer forays a larger proportion of bites was taken on crustose corallines covered by sparse turfs than on bare coralline crusts $\left(\chi^{2}{ }_{3}=\right.$ $10.69, \mathrm{p}<0.05$ ).

Foray size was also affected by foraging depth and by the skeletal density of substrates. However, these effects are partially explained by differences in algal vegetation. On the deeper reef parts ( $>4 \mathrm{~m}$ depth) more bites were taken in long forays than on the shallow reef $\left(\chi_{3}^{2}=67.05, p<0.001\right)$. On the deeper reef parts, a larger proportion of the forays were directed towards the preferred turfs on endolithic algae, compared to the shallow reef zone (31 and $23 \%$ respectively). Similarly, on low-density substrates (Colpophyllia natans, Diploria spp., Montastrea annularis and Madracis mirabilis) more bites were taken in long forays than on high-density substrates (Acropora cervicornis, A. palmata and Agaricia spp.) $\left(\chi_{3}^{2}=146.41\right.$, $\mathrm{p}<0.001)$. Again, the preferred food type - turfs on endolithic algae - occurred in a larger proportion of forays on low-density substrates compared to highdensity substrates ( 46 and $24 \%$ respectively).

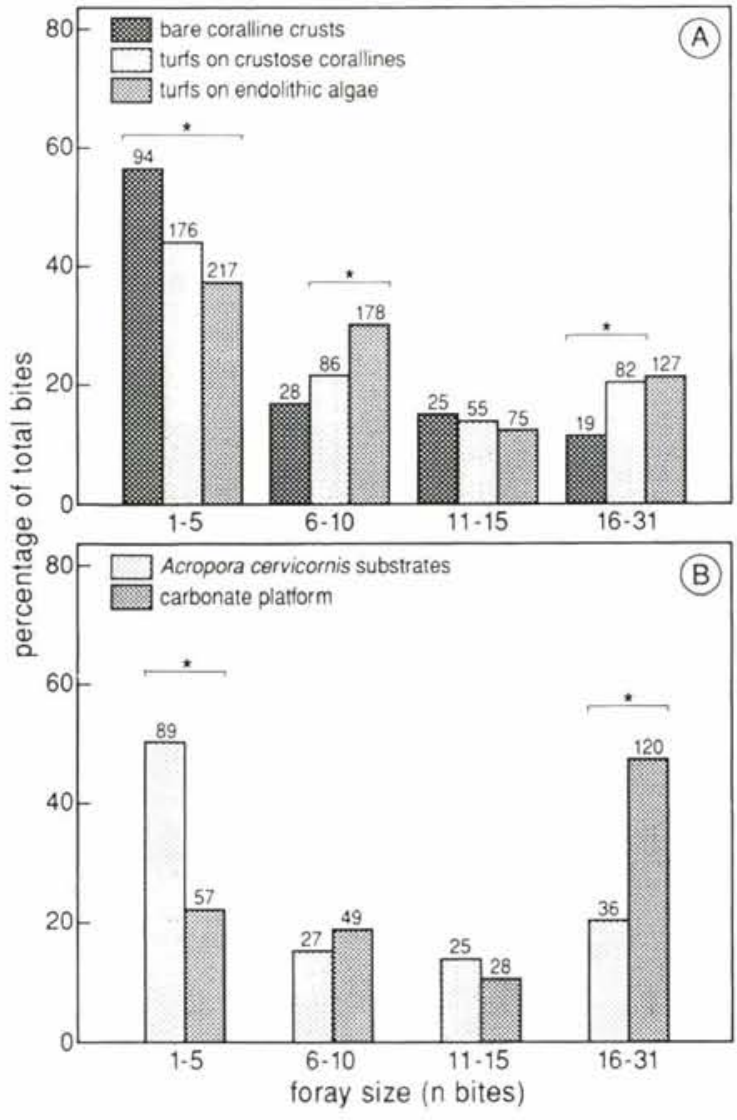

Fig. 5. Scarus vetula. Effect of (A) food type and (B) microhabitat on the frequency distribution of total bites by foray size. Dead Acropora cervicornis substrates represent convex grazing microhabitats, while the carbonate platform is a flat microhabitat for $S$, vetula. Numbers refer to the number of bites; asterisks indicate significant contributions of individual foray size groups to the observed difference in frequency distribution

Another factor affecting foray size is substrate microhabitat. In the gorgone zone, Acropora cervicornis constitutes substrates with convex surfaces, while the carbonate platform is essentially a flat surface. As shown in Fig. 5B, fish took significantly more bites in long forays on flat than on convex substrate surfaces $\left(\chi_{3}^{2}=46.51, p<0.001\right)$. Here, the difference in foray size cannot be explained by differences in algal vegetation, since a larger proportion of bites on the carbonate platform was taken on less favoured food types (coralline crusts with or without epilithic algae: A. cervicornis, $46 \%$; carbonate platform, $56 \%$ ).

\section{Yield per bite}

In Table 4 the yield per bite obtained by Scarus vetula from the 4 main food types is given. The food types are ranked from high to low yield per bite, and 
Table 4. Yield of biomass, protein and energy per bite of different food types for Scarus vetula of $30 \mathrm{~cm}$ fork length. Food types are ranked by yield per bite; percentage of the maximum yield per bite is given in parentheses

\begin{tabular}{|lccc|}
\hline & $\begin{array}{c}\text { Biomass } \\
\left(\mathrm{mg} \mathrm{AFDW} \text { bite }^{-1}\right)\end{array}$ & $\begin{array}{c}\text { Protein } \\
\left(\mathrm{mg} \mathrm{bite}^{-1}\right)\end{array}$ & $\begin{array}{c}\text { Energy } \\
(\mathrm{J} \text { bite }\end{array}$ \\
\hline Large turfs & 3.23 & 0.349 & 62.4 \\
& $(100)$ & $(100)$ & $(100)$ \\
Sparse turfs on & 0.60 & 0.068 & 11.3 \\
endolithic algae & $(19)$ & $(19)$ & $(18)$ \\
Sparse turfs on & 0.46 & 0.047 & 8.4 \\
crustose corallines & $(14)$ & $(13)$ & $(14)$ \\
Crustose corallines & 0.13 & 0.008 & 2.7 \\
& $(4)$ & $(2)$ & $(4)$ \\
\hline
\end{tabular}

the ranking of food types is the same, regardless of whether biomass, protein or energy is chosen as the criterium. Differences in yield are not caused by differences in the size of grazing scars (see above), but result from differences in epilithic algal biomass.

\section{Food intake per bite}

The characteristics of the algal vegetation on the experimental substrates are summarized in Table 5. Only experimental blocks bearing larger or smaller amounts of sparse algal turfs were offered to Scarus vetula in tanks; substrates containing endolithic algae and/or crustose corallines but devoid of epilithic turfs were not used. All vegetation parameters differed significantly between the 2 experimental substrate types. Acropora palmata substrates contained higher algal turfs (ANOVA, $F_{(1,42)}=38.72, \mathrm{p}<0.001$ ), higher cover of epilithic algae (ANOVA, $F_{(1.42)}=6.23, \mathrm{p}<0.017$ ), and higher total algal biomass (ANOVA, $F_{(1.42)}=14.35, \mathrm{p}<$ 0.005 ), but lower cover of crustose corallines (ANOVA, $\left.F_{(1,42)}=20.63, \mathrm{p}<0.001\right)$ than A. cervicornis substrates. Although food intake per bite from A. cervicornis substrates was lower than from $A$. palmata substrates, the difference was not significant $\left(\right.$ ANCOVA, $F_{11,41}=2.10$, $p=0.155$ ). Therefore, in the subsequent analysis, both substrate types were pooled.

The least-squares regression of food intake per bite against fish weight was significant $(\mathrm{r}=0.391, \mathrm{n}=44$, $p=0.009$ ), with the intercept not significantly different from zero $(p=0.219)$. Therefore the regression was forced through the origin (Fig. 6A), as was done for Sparisoma viride (Bruggemann et al. 1994b), to enable comparison.

Differences in food intake per bite within experiments can be explained by differences in algal biomass
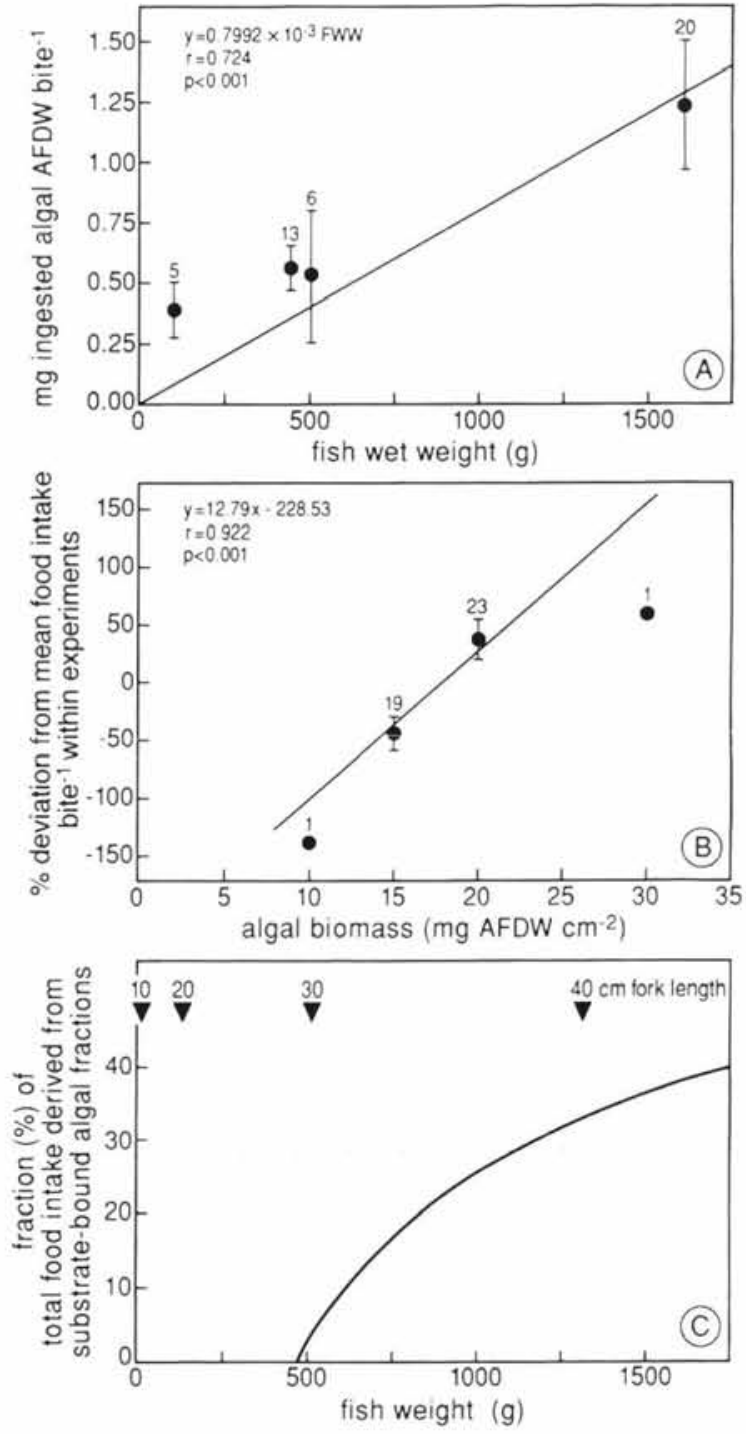

Fig. 6. Scarus vetula. (A) Food intake per bite as a function of fish wet weight (FWW). The least-squares regression line was forced through the origin (intercept was not significantly different from zero, $p>0.05$ ). Error bars indicate SE of mean food intake per bite for each fish (pair); numbers above data points indicate number of experimental blocks. (B) Effect of algal biomass on food intake per bite. The residuals \pm SE of the mean food intake per bite within experiments are plotted against algal biomass on experimental substrates. Calculated least-squares regression line through all experimental data is shown; numbers above data points indicate number of experimental blocks. (C) Estimated percentage of the total food intake derived from crustose and endolithic algae as a function of fish size

on experimental substrates (ANOVA, $F_{(3,40)}=5.32, \mathrm{p}=$ 0.004). In Fig. 6B the percentage deviation from the mean food intake per bite within experiments is plotted against algal biomass. Food intake per bite was not significantly affected by the percentage cover of epi- 
Table 5. Dead coral substrate types and characteristics of associated algal vegetation used in food intake experiments with Scarus vetula. Indicated are the mean $\pm \mathrm{SD}$ for each substrate group

\begin{tabular}{|lccccc|}
\hline Substrate type & $\begin{array}{c}\text { Algal biomass } \\
\left.\text { (mg AFD } \mathrm{cm}^{-2}\right)\end{array}$ & \multicolumn{2}{c|}{$\begin{array}{c}\text { Epilithic algal turfs } \\
(\mathrm{mm} \text { height })\end{array}$} & $\begin{array}{c}\text { Crustose corallines } \\
(\% \text { cover })\end{array}$ & $\begin{array}{c}\text { No. of experi- } \\
\text { mental blocks }\end{array}$ \\
\hline Acropora cervicornis & $14.8 \pm 3.7$ & $1.8 \pm 0.5$ & $46.6 \pm 18.8$ & $40.6 \pm 38.9$ & 13 \\
Acropora palmata & $19.3 \pm 3.6$ & $3.3 \pm 0.7$ & $60.2 \pm 15.5$ & $3.5 \pm 15.8$ & 31 \\
\hline
\end{tabular}

Table 6. Scarus vetula. Mean assimilation efficiencies \pm SD of total AFDW, protein and energy. Each experiment was carried out with 2 fish of similar fork length $( \pm 0.5 \mathrm{~cm})$

\begin{tabular}{|c|c|c|c|c|c|c|}
\hline \multirow[t]{2}{*}{ Life phase } & \multirow{2}{*}{$\begin{array}{l}\text { Mean fish } \\
\text { weight }(\mathrm{g})\end{array}$} & \multirow{2}{*}{$\begin{array}{c}\text { Duration } \\
\text { (d) }\end{array}$} & & \multicolumn{3}{|c|}{ Assimilation efficiency (\%) } \\
\hline & & & & Total AFDW & Protein & Energy \\
\hline Initial phase & 102 & 5 & & $59.6 \pm 6.6$ & $83.2 \pm 1.2$ & $65.0 \pm 5.8$ \\
\hline \multirow[t]{2}{*}{ Initial phase } & 444 & 3 & & $47.5 \pm 2.8$ & $75.0 \pm 1.3$ & $54.5 \pm 2.4$ \\
\hline & & & mean: & $\begin{array}{c}55.1 \pm 8.0 \\
(\mathrm{n}=8)\end{array}$ & $\begin{array}{c}80.1 \pm 4.2 \\
(\mathrm{n}=8)\end{array}$ & $\begin{array}{c}61.0 \pm 7.0 \\
(\mathrm{n}=8)\end{array}$ \\
\hline
\end{tabular}

lithic turfs or of crustose corallines, nor by the canopy height of epilithic turfs.

Fig. 6C shows the estimated percentage of total food intake that was derived from crustose and endolithic algae. Fish up to $29 \mathrm{~cm}$ FL (ca $450 \mathrm{~g} \mathrm{FWW}$ ) ate only epilithic algal turfs, while in larger fish the proportion of substrate-bound algal fractions in the diet increased with size. Fish of $40 \mathrm{~cm}$ FL (1320 g FWW) derived approximately $33 \%$ of their total food intake per bite from endolithic and crustose coralline algae.

\section{Assimilation efficiency of AFDW, protein and energy}

The results of assimilation experiments with Scarus vetula are given in Table 6 . The mean assimilation efficiency for total AFDW over all experimental days and of both fish pairs was $55.1 \pm 8.0 \%(n=8)$. For all experimental days and both fish pairs, the mean protein assimilation efficiency was $80.1 \pm 4.2 \%$, and the mean energy assimilation efficiency was $61.0 \pm 7.0 \%$.

\section{Daily foraging effort}

Daily foraging period. Observations of the time of day when Scarus vetula took their first and last bites, made from January to May on $30 \mathrm{~cm}$ IP fish, indicate that, regardless of season, fish started feeding $57 \pm$ 11 min $(n=6)$ after sunrise and ceased their foraging activity $18 \pm 20 \mathrm{~min}(\mathrm{n}=6)$ after sunset. For this size class, the duration of the daily foraging period at Karpata equals the length of the daylight period minus $0.65 \mathrm{~h}$.
Factors affecting feeding rate. FR of Scarus vetula varied with time of day $\left(\right.$ ANOVA, $F_{(10,111)}=21.70, p<$ 0.001 ), steadily increasing from early morning until noon, followed by a period with highest FRs from noon until approximately $1 \mathrm{~h}$ before dusk (Fig. 7A). This pattern of feeding activity was typical for all scarids observed, regardless of species, size or life phase. Between 12:00 and 17:00 h, FR was not significantly affected by time of day (ANOVA, $F_{(3,68)}=0.34$, $\mathrm{p}=0.797)$. FR was inversely linearly related to $\mathrm{FL}$ (ANOVA, $\left.F_{[3,68)}=16.22, \mathrm{p}<0.001\right)$; the least-squares regression of FR to FL is given in Fig. 7B. Analysis of residuals of the linear regression of FR to FL showed a significant effect of life phase (Scheffé's test, $F_{(2,69)}=$ 55.26, $\mathrm{p}<0.001$ ). In Fig. $7 \mathrm{C}$, the effect of life phase on FR is plotted as feeding rate correction factor $(C)$. TP males had lower FR than both JU and IP fish, whereas FR of JU and IP fish did not differ significantly. During the observation period, seawater temperatures ranged from 25.8 to $29.2^{\circ} \mathrm{C}$. One-way ANCOVA, in which FL was taken as covariate, showed that neither temperature (ANCOVA, $F_{(2,69)}=$ $0.83, \mathrm{p}=0.439$ ) nor time of year (ANCOVA, $F_{(2.68)}=$ $0.61, p=0.547$ ) affected FR significantly between 12:00 and 17:00 h.

Total daily bites. Three daycovers were made for IP Scarus vetula of $29 \pm 2 \mathrm{~cm}$ FL in January, May and August 1990. The proportion of FRs between $12: 00$ and $17: 00 \mathrm{~h}$ to the total daily bites (TDB) averaged $9.33 \pm 0.17(n=3)$. Total daily bites, as dependent on fork length and life phase $(C)$, is estimated using the formula:

$$
\mathrm{TDB}=9.33 \times C \times[3329-(33 \times \mathrm{FL})]
$$



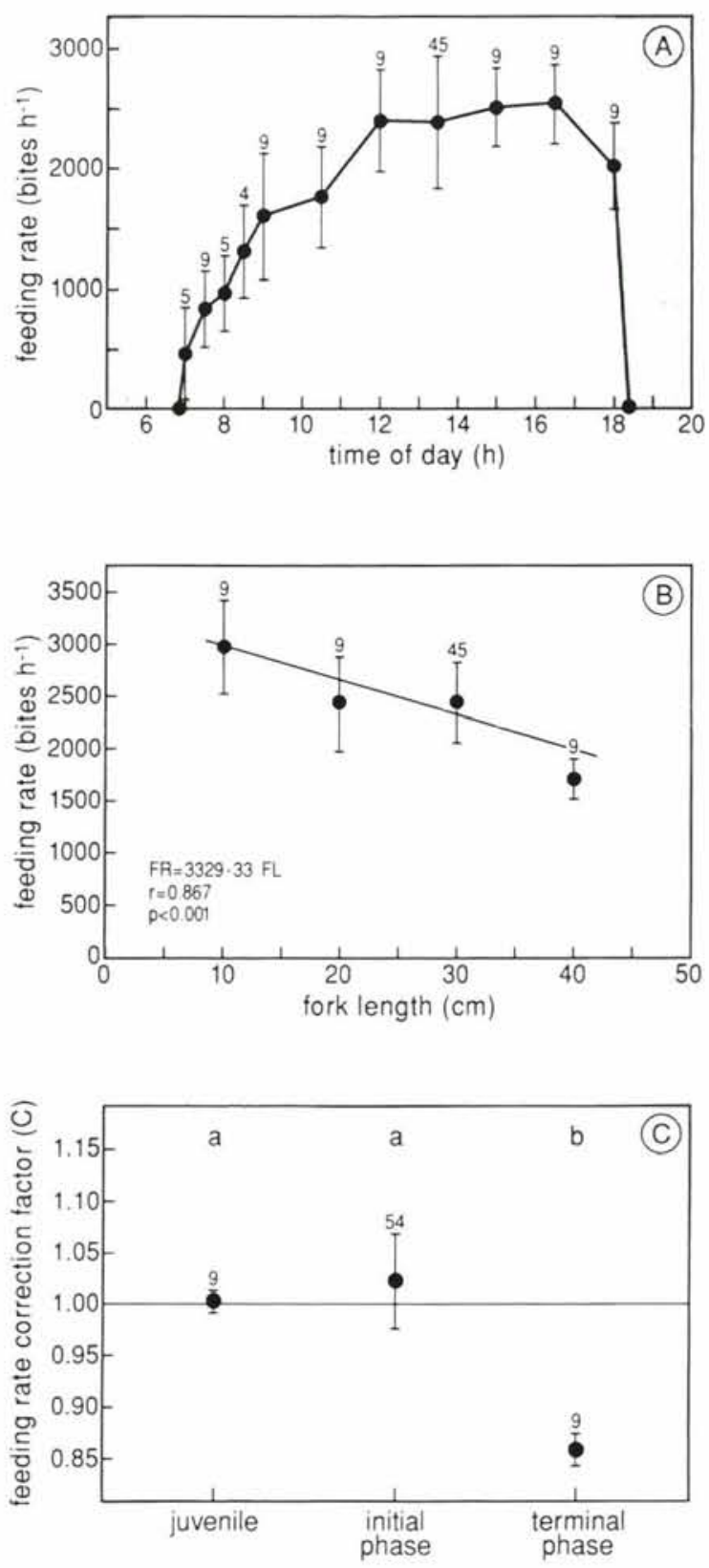

life-phase

Fig. 7. Scarus vetula. (A) Daily pattern of foraging activity. Mean feeding rates \pm SD of all size classes are plotted against time of day. Numbers above data points indicate number of $30 \mathrm{~min}$ observations; shaded area indicates time when sun is below the horizon. (B) Effect of fish fork length $(\mathrm{FL})$ on feeding rate (FR). Least-squares regression is fitted through the weighted means $\pm \mathrm{SD}$ of $\mathrm{FR}$ for each $10 \mathrm{~cm}$ size class. Numbers above data points indicate number of observations between $12: 00$ and $17: 00 \mathrm{~h}$ for each size class. (C) Effect of life phase on feeding rate. Ratio of group means $\pm \mathrm{SD}$ to the regression predictions of FR vs FL are plotted as feeding rate correction factor. Numbers above data points indicate number of observations in each group; different letter codes indicate significant differences between groups

\section{DISCUSSION AND CONCLUSIONS}

\section{Foraging selectivity of Scarus vetula}

Animals can be expected to maximize their energy or specific nutrient intake per unit effort and/or time (Stephens \& Krebs 1986). Thus, the yield of AFDW, protein and energy per bite that fish can attain from different food sources should be predictive of foraging selectivity. Foray size also reflects how animals strive to maximize their food intake. As argued by Bruggemann et al. (1994a), taking more successive bites from highyield food types once they are located and access to them is gained increases food intake per unit time and effort. Thus, foray size will be predictive of foraging selectivity, independent of comparisons between diet composition and available resources. The observed foraging preference of Scarus vetula will be discussed in relation to the yield per bite and foray size.

Except for large turfs, the observed feeding preference of Scarus vetula is correlated with the yield per bite from different food types. Yields of biomass, protein and energy are higher from the preferred food type (sparse turfs on endolithic algae) than from food types which are generally avoided (crustose corallines with algal turfs and bare coralline crusts) (Tables 3 \& 4). The distribution of bites by foray size is also correlated with the yield per bite. More bites are taken in long forays from food types that rank higher in yield per bite than from lower ranking food types (Fig. 5A).

Large turfs enable highest yield of biomass, protein and energy per bite (Table 4), but this food type is eaten less than expected by JU and IP Scarus vetula (Table 3). The apparent avoidance of large turfs is in part caused by the fact that large turfs and macroalgae were lumped into 1 category when the availability of algal food types on the reef was described. Although macroalgae constituted only a small proportion of algal food types available on the reef $(<3 \%)$, the relative abundance of large turfs and macroalgae together is always higher than that of large turfs alone. As macroalgae are not eaten at all by $S$. vetula, large turfs seem to be avoided more than they really are. Macroalgae present on the reef include species like Dictyota spp. and Lobophora variegata, which are rich in secondary compounds that deter grazers (Paul 1992, Steinberg 1992), and are not eaten by $S$, vetula.

The proportion of high-yield food types (large turfs and sparse turfs on endolithic algae) in the diet of Scarus vetula increases with life phase, and thus with size (Table 3 ), indicating that large individuals gain better access to these food patches. This is especially apparent for large turfs. This food type is found mostly inside territories of damselfish where it is relatively inaccessible due to territorial defence by residents. 
Large size may be advantageous in overcoming the territorial defence of damselfish. Thus, body size determines to a large extent the outcome of both intra- and interspecific interactions.

\section{Diet composition of Scarus vetula and Sparisoma viride}

Macroalgae, and to a lesser extent also living corals, are consumed by Sparisoma viride but not by Scarus vetula. However, when diet composition of $S$. vetula (Table 3 ) is compared to that of $S$. viride (Table 3 in Bruggemann et al. 1994a), it is apparent that both species show very similar foraging preferences. Sparse turfs on endolithic algae are preferred while crustose corallines with or without algal turfs are avoided. Large turfs are preferred by $S$. viride, and possibly also by $S$. vetula. In conclusion, the diets of these sympatric species overlap to a large extent, although the relative amounts of epilithic and substrate-bound algae ingested are very different (see below).

\section{Utilization of grazing substrates in relation to feeding mode}

Feeding preference by Scarus vetula may be determined by factors other than algal vegetation, such as substrate microhabitat. $S$. vetula prefers to graze on flat rather than concave substrate surfaces, as indicated by a larger proportion of the bites (Fig. 4A) and the long forays on the (flat) carbonate platform (Fig. 5B). Furthermore, in the gorgone zone the carbonate platform is a preferred substrate type (Table 1), while dead Madracis mirabilis and Diploria spp. substrates are avoided as grazing substrates (Table 2). The fine branches ( $M$. mirabilis) and the highly rugose surface (Diploria spp.) of these corals offer no smooth grazing substrate for $S$. vetula. In contrast, substrate preference in Sparisoma viride is largely determined by skeletal density (Bruggemann et al. 1994a), and adults prefer grazing on concave substrate surfaces (Fig. 4B).

Differences in substrate preference are related to the feeding mode of the 2 species. Scarus vetula takes quick bites (Fig. 2), which most often do not leave grazing scars (Fig. 3). Sparisoma viride takes bites more slowly (Fig. 2), the majority of which leave visible grazing scars (Fig. 3). Based on these functional differences in grazing, $S$. vetula can be classified as a scraper, and $S$. viride as an excavator (sensu Bellwood \& Choat 1990). This distinction between the scraping and excavating feeding modes employed by these species has been delineated in previous studies on bioerosion by Caribbean scarids (Gygi 1975, Frydl \& Stearn 1978).
Species-specific differences in feeding mode are further reflected in the size of the grazing scars and in the morphology of the dental plates. Surface area and volume of grazing scars produced by $S$. viride are larger than those made by $S$. vetula. The cutting edges of both the premaxilla and the dentary of the 2 species have a different morphology. Dental plates of $S$. viride are crenate as a result of alternately protruding teeth on the vertical tooth row on each cutting edge (good illustration in Gygi 1975, p. 346). S. vetula, on the other hand, has dental plates with relatively even cutting edges. Premaxilla and dentary are set with broadedged teeth that are worn to an even edge (pers. obs.). Bellwood \& Choat (1990) have shown that differences in osteology and myology in jaw structures are related to functional differences in grazing mode between members of one scarid subfamily (Scarinae). As shown here, similar functional differences exist between members of different subfamilies of scarids. Juvenile feeding behaviour, however, is less differentiated between these species. Although bite rates of juvenile fish are higher for $S$. vetula than for $S$. viride, juveniles of both species most often do not leave grazing scars on the substrate (Fig. 3), and prefer flat substrate microhabitats (Fig. 4A, B). Due to its feeding mode, S. vetula ingests mainly epilithic algal turfs, while substratebound algal fractions form the larger part of the food ingested by adult $S$. viride. The food ingested by juvenile $S$. viride consists primarily of epilithic turfs. These conclusions are confirmed by experiments in which the food intake per bite was determined.

\section{Food intake and assimilation in relation to feeding mode}

The food intake per bite attained by Scarus vetula (Fig. 6A) is ca 3 times lower than that of Sparisoma viride (Fig. 1 in Bruggemann et al. 1994b), because substrate-bound algal fractions are exploited less by the former species (compare Fig. 6C with Fig. 3 in Bruggemann et al. 1994b). Differences in algal biomass affect food intake per bite by $S$. vetula more than in $S$. viride, as indicated by significantly different $(\mathrm{p}<$ 0.05 ) regression slopes of the residuals of food intake per bite to algal biomass (12.79 and 5.28 for $S$. vetula and $S$. viride respectively) (compare Fig. $6 \mathrm{~B}$ with Fig. 2 in Bruggemann et al. 1994b). As the biomass of substrate-bound algal fractions is relatively constant, differences in algal biomass are mainly caused by those of epilithic algae. Food intake by $S$. vetula, employing a scraping feeding mode, will be determined primarily by the availability and biomass of epilithic algae. For the excavator $S$. viride, food intake is determined by accessibility and biomass of both epilithic and sub- 
Table 7. Scarus vetula. Daily intake and assimilation of algal AFDW, protein and energy by different life phases and sizeclasses on the shallow reef. nd: no data

\begin{tabular}{|lccccccc|}
\hline Life phase & $\begin{array}{c}\text { Fork } \\
\text { length } \\
(\mathrm{cm})\end{array}$ & $\begin{array}{c}\text { Fish } \\
\text { weight } \\
(\mathrm{g})\end{array}$ & $\begin{array}{c}\text { Total daily } \\
\text { bites }\end{array}$ & $\begin{array}{c}\text { Daily food } \\
\text { intake } \\
(\mathrm{g} \text { AFDW })\end{array}$ & \multicolumn{2}{c|}{$\begin{array}{c}\text { Daily assimilation } \\
\text { Protein } \\
(\mathrm{g} \text { AFDW })\end{array}$} & $\begin{array}{c}\text { Energy } \\
(\mathrm{g})\end{array}$ \\
\hline Juvenile & 10 & 14 & 28055 & 0.36 & nd & nd & nd \\
Initial phase & 20 & 134 & 25483 & 3.21 & 1.77 & 0.28 & 34 \\
Initial phase & 30 & 511 & 22339 & 10.74 & 5.92 & 0.92 & 125 \\
Terminal phase & 40 & 1320 & 16128 & 25.85 & nd & nd \\
\hline
\end{tabular}

strate-bound algal fractions and by substrate density. It will be less affected by changes in epilithic biomass, which constitute only a minor fraction of the total algal biomass.

Assimilation efficiencies of AFDW, protein and energy in Scarus vetula (Table 6) fall in the range of values reported for other reef fish that feed on benthic algae (see review by Horn 1989), but are higher than the assimilation efficiency attained by Sparisoma viride on the shallow reef (Tables 2 \& 3 in Bruggemann et al. 1994b). In $S$. viride a large part of the food ingested consists of substrate-bound algal fractions, and the assimilation efficiencies are largely determined by the skeletal density of the substrate. The grinding efficiency of the pharyngeal apparatus determines how much of the ingested food can be made accessible to digestion. Digestion of epilithic algae, the major food source for $S$. vetula, is probably less constrained by grinding efficiency of the fish, enabling higher assimilation efficiencies. As they grow, $S$. vetula ingest increasing amounts of substrate-bound algal fractions, which may affect the digestibility of ingested food. For $S$. viride, however, in which the proportion of substrate-bound algae in the diet also increases with size, no effect of size on assimilation efficiency was found.

\section{Daily intake and assimilation of food, protein and energy in the field}

The experimentally determined food intake and assimilation efficiency form the basis for estimating the daily intake and assimilation of food, protein and energy by Scarus vetula. Differences in algal biomass between the substrates used during experiments and those found in the field have to be corrected for. This is made possible by using the least-squares regression describing the effect of algal biomass on food intake per bite (Fig. 6B). As the size of grazing scars is not affected by food type, substrate density or substrate microhabitat, it is assumed that food intake by $S$. vetula is affected only by algal biomass. A complicating factor is that large fish ( $>30 \mathrm{~cm} \mathrm{FL}$ ) foraging on the reef take bigger bites than similarly sized fish kept in tanks. A food intake conversion factor, from experiments to the field situation, was calculated by weighting the correction factors for surface area and volume with the relative contribution of epilithic and substrate-bound algal fractions in the bite (Fig. 6C). For fish $>30 \mathrm{~cm}$ FL this conversion factor was 1.28. Total daily bites and daily intake of total AFDW was calculated for 4 size classes of $S$, vetula foraging on the shallow reef (Table 7), using the equations described in this paper and the diet composition of the different life phases (Table 3). Intake of protein and energy was calculated from the food intake per bite (Fig. 6A), the proportion of the food derived from epilithic and substrate-bound algal fractions (Fig. 6C), and the biochemical composition of the food (Table 5 in Bruggemann et al. 1994a). Daily amounts of food, protein and energy assimilated were calculated using the mean assimilation efficiencies of Table 6 .

Daily food intake by Scarus vetula foraging in the shallow reef zone was estimated to be 19.6 to $26.1 \mathrm{mg}$ AFDW $\mathrm{g}^{-1}$ FWW, depending on life phase and size (Table 7). Daily food intake is equivalent to 7.9 to $10.6 \mathrm{mg}$ algal $\mathrm{C} \mathrm{g}^{-1}$ FWW if algae are assumed to contain $40.5 \%$ C (Bruggemann et al. 1994b). These values are within the range of values reported for Sparisoma viride (Table 6 in Bruggemann et al. 1994b: 6.9 to $22.4 \mathrm{mg} \mathrm{C} \mathrm{g}^{-1} \mathrm{FWW}$ ), and some other herbivorous reef fish (Fig. 5A in Bruggemann et al. 1994b). For S. vetula foraging in the drop-off reef zone, the estimated food intake was 10 to $15 \%$ higher than for individuals foraging on the shallow reef, because of a higher proportion of high-yield food types (large turfs and sparse turfs on endolithic algae) in the diet (Table 3). In contrast, daily food intake of deep foraging $S$. viride was almost twice as high as that estimated for fish foraging on the shallow reef, which was primarily due to increased availability of low-density grazing substrates, enabling the excavator $S$. viride to attain higher yields per bite.

The daily amounts of assimilated AFDW, protein and energy by IP Scarus vetula are similar to the values found for Sparisoma viride. Thus, the lower food intake 
Table 8. Summary of differences in foraging behaviour between Scarus vetula and Sparisoma viride of $30 \mathrm{~cm}$ fork length

\begin{tabular}{|lcc|}
\hline Foraging characteristic & S. vetula & S. viride \\
\hline Mean foray size (no. of bites) & 4.2 & 3.6 \\
Bite rate (bites s ${ }^{-1}$ ) & 1.1 & 0.4 \\
Frequency of grazing scars (\%) & 38 & 75 \\
Shape of grazing scars & Shallow, elongate & Deep, wide \\
Preferred substrate microhabitat & Flat & Concave \\
Main algal food source & Epilithic & Substrate-bound \\
Food intake per bite (g AFDW d ${ }^{-1}$ ) & 0.5 & $2.0-3.5^{\text {a }}$ \\
Assimilation efficiency (\% AFDW) & 55 & $20-70^{\mathrm{a}}$ \\
Daily assimilated AFDW (g d ${ }^{-1}$ ) & 5.9 & $3.6-12.7^{\text {a }}$ \\
& & \\
${ }^{\text {a Depending on foraging depth }}$ & & \\
\hline
\end{tabular}

The effect of the exploitation of resources by one species on the availability of resources for the other is not symmetrical. Imagine Sparisoma viride taking a bite: all epilithic algae are removed from the surface, and a considerable part of the substrate-bound algal fractions are excavated as well. Obviously there is little left to harvest for Scarus vetula. On the other hand, after a bite taken by $S$. vetula, $S$. viride is still capable of harvesting the crustose and endolithic algae that are left. These 2 herbivores thus play fundamentally different roles in the dynamics of algal vegetation. per bite by $S$. vetula is offset by its higher feeding rates, resulting in the daily number of bites being 2.8 to 3.6 times that of similarly sized $S$. viride, and by more efficient assimilation of the food ingested. An important conclusion, therefore, is that, in spite of different feeding modes and different fractions of the primary production harvested, daily amounts of assimilated nutrients and energy for both species are almost the same. In Table 8 the differences in foraging behaviour between adult fish ( $30 \mathrm{~cm} \mathrm{FL}$ ) of both scarid species are summarized.

\section{Competition, coexistence, and the importance of optimal resources}

The parrotfish described here occupy the same reef habitats, show similar foraging selectivity, and to a large extent graze on the same dead coral substrates. Interspecific competition for food resources seems therefore probable. Food competition would be indicated by frequent occurrence of aggressive interactions between Scarus vetula and Sparisoma viride. However, $S$. viride has hardly any aggressive interactions with other grazing scarids (J. M. van Rooij pers. comm.) found that . Possibly, algal food resources cannot be economically defended against interspecific competitors. On the other hand, competition may be reduced by resource partitioning. In this study we have demonstrated than $S$. vetula and $S$. viride exploit algal resources differently. Differences in feeding mode cause these species to select different microhabitats, which will probably result in some spatial segregation of grazing sites on the level of individual bites. Moreover, the suitability of substrates for grazing differs between species, resulting in different substrate preferences. Identifying these species-specific differences in optimal resources is a step beyond classifying scarids as a uniform group of consumers of algal turfs.
Acknowledgements. We are grateful to all students and participants of the 'Groninger parrotfish study' for their help during field observations and laboratory experiments. We specifically thank Jaap Begeman, Els Bosma, Onno Diekmann, Anne van Kessel and Piet Verburg for their enthusiastic contribution. The Bonaire Marine Park authorities granted us permission to work on the reefs, and offered working facilities at Karpata Ecological Centre. Further working facilities were offered by the Caribbean Marine Biological Institute at Curaçao. Marcultura at Bonaire kindly donated 2 fish tanks which were installed with the help of Jan van der Kamp. The figures were drawn by Dick Visser, while the comments of 2 anonymous reviewers were helpful for improving the manuscript. J.H.B. was supported by a grant from the Netherlands Foundation for the Advancement of Tropical Research (WOTRO) W84-280. M.W.M.K. received financial support from the Beijerinck Popping Foundation and the Royal Dutch Academy of Sciences.

\section{LITERATURE CITED}

Bellwood, D. R., Choat, H. (1990). A functional analysis of grazing in parrotfish (family Scaridae): the ecological implications. Envir. Biol. Fish. 28: 189-214

Bruggemann, J. H., van Oppen, M. J. H., Breeman, A. M. (1994a). Foraging by the stoplight parrotfish Sparisoma viride. 1 . Food selection in different, socially determined habitats. Mar. Ecol. Prog. Ser. 106: 41-55

Bruggemann, J. H., Begeman, J., Bosma, E. M., Verburg, P., Breeman, A. M. (1994b). Foraging by the stoplight parrotfish Sparisoma viride. II. Intake and assimilation of food, protein, and energy. Mar. Ecol. Prog. Ser. 106: 57-71

Carpenter, R. C. (1986). Partitioning herbivory and its effects on coral reef algal communities. Ecol. Monogr. 56: $345-363$

Carpenter, R. C. (1990). Mass mortality of Diadema antillarum. II. Effects on population densities and grazing intensity of parrotfish and surgeonfishes. Mar. Biol. 104: $79-86$

Choat, J. H. (1991). The biology of herbivorous fishes on coral reefs. In: Sale, P. F. (ed.) Ecology of fishes on coral reefs. Academic Press, London, p. 120-155

Dodge, R. E., Thomson, J. (1974). The natural radiochemicals and growth records in contemporary hermatypic corals from the Atlantic and Caribbean. Earth Planet. Sci. Lett. 23: $313-322$ 
Dring, M. J. (1984). Photoperiodism and phycology. In: Round, F. E., Chapman, D. J. (eds.) Progress in phycological research, Vol. 3. Elsevier Biomedical Press, Amsterdam, p. $159-192$

Ebersole, J. P. (1985). Niche separation of two damselfish species by aggression and differential microhabitat utilization. Ecology 66: 14-20

Frydl, P., Stearn, C. W. (1978). Rate of bioerosion by parrotfishes in Barbados reef environments. J. sedim. Petrol. 48: $1149-1158$

Goldman, B., Talbot, F. H. (1976). Aspects of the ecology of coral reef fishes. In: Jones, O. A., Endean, R. (eds.) Biology and geology of coral reefs, Vol. 3. Academic Press, New York, p. 125-154

Gygi, R. A. (1975). Sparisoma viride (Bonnaterre), the stoplight parrotfish, a major sediment producer on coral reefs of Bermuda? Eclogae geol. Helv. 68: 327-359

Hatcher, B. G. (1983). Grazing in coral reef ecosystems. In: Barnes, D. J. (ed.) Perspectives on coral reefs. The Australian Institute of Marine Science, Townsville, p. 164-179

Hatcher, B. G., Larkum, A. W. D. (1983). An experimental analysis of factors controlling the standing crop of the epilithic algal community on a coral reef. J. exp. mar. Biol. Ecol. 69: 61-84

Hay, M. E., Taylor, P. R. (1985). Competition between herbivorous fishes and urchins on Caribbean reefs. Oecologia 65: $591-598$

Horn, M. H. (1989). Biology of marine herbivorous fishes. Oceanogr. mar. Biol. A. Rev. 27: 167-272

Norusis, M. J. (1990). SPSS/PC +4.0 for the IBM PC/XT/AT and PS/2. Vol. I, Base manual; Vol. II, Statistics; Vol. III, Advanced statistics. SPSS, Inc., Chicago

Ogden, J. C., Lobel, P. S. (1978). The role of herbivorous fishes and urchins in coral reef communities. Environ. Biol. Fish. 3: $49-63$

Paul, V. J. (1992). Seaweed chemical defenses on coral reefs. In: Paul, V. J. (ed.) Ecological roles of marine natural products. Cornell University Press, New York, p. 24-50

Porter, J. W. (1972). Patterns of species diversity in Caribbean reef corals. Ecology 53: 745-748

Randall, J. E. (1968). Caribbean reef fishes. T. F. H. Publications, Hong Kong.

Robertson, D. R. (1991). Increases in surgeonfish populations after mass mortality of the sea urchin Diadema antillarum

This article was submitted to the editor in Panama indicate food limitation. Mar. Biol. 111: $437-444$

Robertson, D. R., Warner, R. R. (1978). Sexual patterns in the labroid fishes of the Western Caribbean. II. The parrotfishes (Scaridae). Smithson. Contr. Zool. 255: 1-26

Russ, G. R. (1984a). Distribution and abundance of herbivorous grazing fishes in the central Great Barrier Reef. I. Levels of variability across the entire continental shelf. Mar. Ecol. Prog. Ser. 20: 23-34

Russ, G. R. (1984b). Distribution and abundance of herbivorous grazing fishes in the central Great Barrier Reef. II. Patterns of zonation of mid-shelf and outershelf reefs. Mar. Ecol. Prog. Ser. 20: 35-44

Russ, G. R., St. John, J. (1988). Diets, growth rates and secondary production of herbivorous coral reef fishes. In: Choat, J. H. et al. (eds.) Proc. 6th int. coral Reef Symp. Vol. 2. Sixth International Coral Reef Symposium Committee, Townsville, p. $37-43$

Schoener, T. W. (1974). Resource partitioning in ecological communities. Science 185: 27-39

Sokal, R. R., Rohlf, F. J. (1981). Biometry. W. H. Freeman and Company, New York

Steinberg, P. D. (1992). Geographical variation in the interaction between marine herbivores and brown algal secondary metabolites. In: Paul, V. J. (ed.) Ecological roles of marine natural products. Cornell University Press, New York, p. 51-92

Steneck, R. S. (1983). Quantifying herbivory on coral reefs: just scratching the surface and still biting off more than we can chew. In: Reaka, M. L. (ed.) The ecology of deep and shallow coral reefs. National Oceanic and Atmosphere Administration, Rockville, MD, p. 103-111

Steneck, R. S. (1988). Herbivory on coral reefs: a synthesis. In: Choat, J. H. et al. (eds.) Proc. 6th int. coral Reef Symp. Vol. 1. Sixth International Coral Reef Symposium Committee, Townsville, p. 37-49

Stephens, D. W., Krebs, J. R. (1986). Foraging theory. Princeton University Press, Princeton, NJ

Wellington, G. M., Victor, B. C. (1985). El Niño mass coral mortality: a test of resource limitation in a coral reef damselfish population. Oecologia 68: 15-19

Williams, D. McB. (1986). Temporal variation in the structure of reef slope fish communities (central Great Barrier Reef): short-term effects of Acanthaster planci infestation. Mar. Ecol. Prog. Ser. 28: 157-164

Manuscript first received: February 3, 1994

Revised version accepted: May 9, 1994 